\title{
Hell revisited: A socio-critical enquiry into the roots and relevance of hell for the church today
}

\author{
Hanré Janse van Rensburg \& Ernest van Eck ${ }^{1}$ \\ Department of New Testament Studies \\ University of Pretoria
}

\begin{abstract}
Hell is being written out of theology and banned from serious conversation; for most scholars and modern-minded people it has more or less become a theoretical issue. Yet it remains alive and burning in the Western mind - there has been a surge in the amount of popular literature written on the subject from the 1990's onwards. Why the sudden interest? Is there a pattern or social trend that could begin to explain the phenomenon? Part of the responsible way of dealing with the history of a concept such as hell is to point towards the social and political reasons for the emergence and need for certain concepts in particular contexts and circumstances, as they are all utilitarian concepts which are employed and abandoned as needs change and sentiments shift. This article will investigate the rise of the concept of hell by investigating the ancient sources in which it first appeared, in order to establish what factors made the concept popular then and now. In doing so, a continuum will be identified between the first origin of these ideas and their present popularity.
\end{abstract}

\section{A DISAPPEARING ACT}

There are two realities that cannot be denied or escaped from: Life is short and death is a certainty, and there are few people who can honestly say that they have no interest in what happens after death - even those who are uncomfortable talking about the subject (Burger 2003:5). Everyone, it seems, has a firm position on hell. Scoffers dismiss it contemptuously as a transparent scare tactic. Others, more moderate, construe it broadly as a

\footnotetext{
${ }^{1}$ This article is a reworked version of Hanré Janse van Rensburg's MDiv dissertation, titled "Hell revisited: A socio-critical enquiry into the roots and relevance of hell for the church today", in the Department of New Testament Studies, Faculty of Theology, University of Pretoria, with Prof Dr Ernest van Eck as supervisor.
} 
symbol of turmoil, despair and alienation (Bernstein 1993:ix). Yet whether one denies it altogether or interprets it figuratively as an aspect of human psychology, the classic hell of fire and brimstone, outer darkness, weeping and gnashing of teeth maintains a definite presence. Christianity is a religion of salvation in which believers have always anticipated some type of postmortem bliss. This belief in salvation for the faithful has usually meant nonsalvation for others; variously imagined as eternal torment, alienation from God or annihilation at some point after death (Trumbower 2001:3). Although in recent years there has been a turn in the neglect of the doctrine of hell, most of this reflection occurs against the backdrop of the supposed untenability of the traditional view. Moreover, the traditional view is held no longer to accord with contemporary cultural norms and values and hence is said to be culturally unavailable (Van Holten 2003:457), which has meant that the past century or more has seen a gentle but sure erosion of certain beliefs which had been taken for granted in the general culture, and particularly in the Christian world (Helm 1989:15). Admittedly, hell is an unpleasant topic - unbelievers disbelieve in it and most Christians ignore it. Even the staunchly Biblical diehards are often silent out of embarrassment; hell, more than any other doctrine of the Bible, seems to be out of step with our times (Lutzer 2000:91). The spirit of the age is certainly not conducive to the subject of hell existentialism lives for this world rather than the next and hedonism seeks pleasure and avoids pain. Most people feel that there are enough troubles to cope with in the here and now, so why add distant worries about the there and then? Coupled with this major shift in emphasis is the move away from the traditional understanding of hell (Pawson 1992:6). In much recent literature alternative doctrines of hell are developed, whereas the classical view is rejected summarily (Van Holten 2003:458). This means that, though the doctrine of hell is one of the tenets of traditional Christian belief, at present it does not seem to enjoy much popularity among Christian scholars and leaders (Van Holten 2003:457). One rarely hears the doctrine explicitly addressed in a Christian church these days, and if hell is spoken about at all, it is commonly referred to in rather vague and tentative ways. Indeed, it would be no exaggeration to claim that the average Christian believer finds it difficult to explain what function (if any) the doctrine of hell plays in his/her own faith (Van Holten 2003:457). Has this happened by default or has it been deliberate? Has hell simply been overlooked or was it consciously suppressed? Yet hell, it seems, is an idea that is as hard to live with as it is to do without - those who claim fervently to disbelief in the place are often inclined to wish others there; those who do believe in the place often wish 
they didn't have to, but it is sadly easier for them to disbelieve in heaven (Wetzel 2002:375).

\section{HELL: A HOT DEBATE}

\subsection{The problem}

For many people living in a modern world, hell has disappeared as a culturally viable option for talking about the afterlife. To many modern people the word hell is nothing more than a byword in vulgar speech (Craffert 1999:72). "Hell disappeared. And no one noticed." With that terse observation American church historian Martin Marty summarised our attitude toward a vanishing doctrine that received careful attention in previous generations (Lutzer 2000:91). Writing in the sixties a British journalist observed that: "Forty years ago we stopped believing in hell; twenty years ago we stopped believing in heaven" (Pawson 1992:15). A recent Newsweek article says: "Today, hell is theology's H-word, a subject too trite for serious scholarship." Gordon Kaufman of Harvard Divinity School believes we have gone through a transformation of ideas and says; "I don't think there can be any future for heaven and hell" (Lutzer 2000:91). In the vast majority of churches, hell is rarely if ever mentioned - there is a widespread retreat from this traditional item of faith (Pawson 1992:15). A report of the Church of England states that the notion of everlasting damnation is incompatible with the affirmation that God is love, corresponding to a strong trend in modern theology. In most New Testament theologies hell hardly exists, even many evangelical theologians are disturbed by notions of hell (Räisänen 2007:1). John Robinson states that Christ remains on the cross as long as one sinner remains in hell. James Mill expresses what many have felt when he says that he will call no being good who is not what he means when he uses that word of fellow creatures - if there be a Being who can send him to hell for this, to hell he will go. One man even said that he would not want to be in heaven with a God who sends people to hell. "If such a God exists, he is the devil" (Lutzer 2000:92). A more subtle form of reduction relates to our existential preoccupation with our present situation; so much so that the next world has become unreal and irrelevant (Pawson 1992:12). This world is the only world that really matters and we make our own heaven or hell here on earth, which means that there is neither pleasure nor pain beyond the grave. All these attitudes and beliefs centre on a person's awareness of his/her own responsibility, and especially accountability to God. The idea of personal accountability has always been ridiculed by some, and ignored by many others; and yet it was possible, at one time, to take such beliefs for granted both in public life and in Christian preaching (Helm 1989:15). There are two significant implications of this 
common outlook: One is the transference of retribution from the eternal to the temporal sphere, the other is the transference of judgement from the divine to the human realm (Pawson 1992:13). Hell is no longer an imposed punishment, but a freely chosen preference, even a right to be defended - it is no longer a verdict of the divine but a victory of the human will, and man is free to escape from this hell of his own making by committing suicide (Pawson 1992:13).

Yet mostly when talking or writing about the subject of hell no explanation of the concept is given, as most writers assume, correctly, that the majority of people are well acquainted with the idea of myriads of human souls tormented by unbearable heat. Such a picture is deeply rooted in Western folklore and is an example of the most effective communication in the history of the church (Pawson 1992:10). In the days when the majority of worshippers were illiterate and the Bible remained a closed book studied only by Latin scholars, Christian doctrines were communicated to the eye rather than the ear - both in a dynamic mode (ritual) and a static one (stained glass, sculpture, painting; Pawson 1992:11). Few cathedrals of the Middle Ages lacked a vivid visual reminder of the destiny of the unsaved, and such lurid scenes left and indelible impression. This medieval concept of hell has survived almost intact, in spite of the Protestant Reformation (Pawson 1992:11).

And this is the dichotomy - hell is being written out of theology and banned from serious conversation. Systematic theologians go pretty far in repressing the idea of hell: it is, for instance, stated that while hell is a "real possibility of human freedom" it is very much the question whether this possibility has ever been or will ever be realised. The unmentioned expectation is that it will not become a reality for anybody. For these scholars hell has become more or less a theoretical issue. Yet it remains alive and burning (though suppressed) in the Western mind. Recent polls show that $30 \%$ of the British say they believe in hell, and in Europe as a whole $28 \%$ of the population are said to share this belief: In Northern Ireland $61 \%$, in Catholic Malta 76\% and in Finland 25\% (Räisänen 2005:2). Among active church-goers the rates are higher - the majority of them believe in hell. Last year the issue entered the agenda in Finland as a survey found that one third of Finnish pastors do not believe in hell, at least not firmly - a result which caused some consternation among the general public (Räisänen 2005:2). So even though it is not taken seriously by modern scholars, it still remains in the news and receives much publicity, even if it is only to refute the idea and its consequences. So hell is still a familiar feature in our mental landscape, but the familiarity no longer inspires fear or terror - modern man has come to terms with it (Pawson 1992:12). It is ironic that the word itself is used far more outside than inside the church. Together with related curses, it is one of the 
most common swear-words in daily use - "hell" is now used so frequently that it is considered no more than a mild expletive (Pawson 1992:12). Hell is also being trivialised in our day through comedy - jokes exploit the widespread knowledge of the Christian belief. And yet a certain type of religious personality has loved to dwell on the subject: to embellish it in lurid detail and to linger on the pains and the hopelessness. In some Christian religious circles the teaching of hell remains one of the cornerstones of evangelisation. Even when it is not explicitly stated, hell functions as the antipole of heaven (Craffert 1999:71). For some people, a description of and belief in hell constitutes a part of their cultural perception of this life, the afterlife and the conditions to be expected in each. The fascination with evil has become particularly strong again in the post-modern world. But even in the Middle Ages it awakened atrocious and terrifying visions which painters delighted to paint in elaborate detail in churches (Moltmann 1999:43).

Now, most people would agree that some deserve no less than hell; we probably all have lists of candidates for the lake of fire. A recent Gallup poll revealed that two-thirds of the American population believed in heaven and that they were sure to go there; the same proportion also said they knew someone who was sure to go to hell (Pawson 1992:5). But whatever people may occasionally think privately, the matters are not publicly discussed nor openly accepted. They have either been completely submerged by other things or have become warped or been caricatured into unrecognisable forms (Helm 1989:32). Given the Medieval imagery with which the concept of hell is still loaded, and the vengeful concept of God that it often presupposes, this reluctance is more than understandable (Van Holten 2003:457). To put it simply, to us the punishment of hell does not fit the crime - yes, all men do some evil and a few do great evils, but nothing that anyone has ever done can justify eternal torment. Thus millions of Westerners believe in some kind of afterlife, but it is one of bliss, not misery (Lutzer 2000:93). Hell, it seems, is an idea that is as hard to live with as it is to do without - those who claim fervently to disbelief in the place are often inclined to wish others there; those who do believe in the place often wish they didn't have to, but it is sadly easier for them to disbelieve in heaven (Wetzel 2002:375).

\subsection{This exercise}

What is interesting to note is that, in the midst of this worldwide trend in the theological world, there has been a surge in the amount of popular literature written on the subject from the 1990's onwards. People on the streets show a growing interest in the topic, and buy from prophetic visions of hell (e. $g$.

Baxter 1993; Thomas 2003) to more theological treatises on the subject (e. g. Burger 2003; Lutzer 2000). So even though hell is not taken seriously any 
more by most scholars and modern-minded people, it is still taken seriously and talked about. Why the sudden interest? What are the things being said on the subject? Where do the ideas now being spouted come from? What lead to the origin of these ideas? Comprehending the rise of hell entails investigating the historical experiences and ethical debates recorded in the ancient sources of Egypt, Mesopotamia, Israel, Greece, Rome and the early Christian community. These people shaped the idea of hell as they asserted and denied, accepted and rejected their own and each others' answers to questions concerning death and the dead, justice and evil (Bernstein 1993:ix). Can a link be found to the topic's growing popularity today? Is there a pattern or social trend that can begin to explain the phenomenon? What made hell popular then and now?

Part of the responsible way of dealing with the history of concepts, such as resurrection and life after death, is to point towards the social and political reasons for the emergence and need for certain concepts in particular contexts and circumstances (Craffert 1999:60). Resurrection, immortality and other notions about the afterlife, such as a shadowy existence in Sheol, are all utilitarian concepts which are employed and abandoned as needs change and sentiments shift (Craffert 1999:60). Ideas arise only in specific cultural contexts, and in turn the new ideas help give shape to new cultural contexts (Trumbower 2001:9). Often the claims of eternal truth in a specific period turn out to be the expression of a specific class and interest position. And often the usefulness of one concept ceases to satisfy under changing conditions (Craffert 1999:61). But though these symbols, phantasms or images are imaginary, the act of inventing them takes on a historical dimension, particularly when they are shared by large numbers of people over long periods of time and when they differ from the ideas expressed in epic poetry or the explanations articulated in philosophy (Bernstein 1993:92). This work is an attempt to investigate and possibly answer these questions. So the main question becomes: Is there a continuum to be identified between the first origin of these ideas and their present popularity?

\section{THE TRADITION: ETERNAL TORMENT}

When looking at the interpretation of ideas in modern times, we can usefully identify three principal ways of understanding the nature of doctrinal beliefs: propositional, experiential-expressivist and cultural-linguistic (Stoddard \& Pryce 2005:130-131). A propositional outlook considers doctrine to be of the form of first order propositions asserting ontological truth. In our context this means that hell is real, although beyond our world. The experientialexpressivist (commonly the liberal outlook) might draw on the language of hell 
to articulate the common human experience of exclusion in social relationships, perhaps extending this to the existential alienation that some feel from the Divine. In turn, both propositionalist and experiential-expressivist epistemologies differ from the cultural-linguistic approach to doctrine. In this context a cultural-linguistic view might interpret the narratives of hell as ways of holding community boundaries as a distinctively acting people and as enabling the Christian community to speak of God's "no" to evil. As was seen in the previous chapter, traditional/propositional ideas have become ever more popular in recent times.

Some people believe that, a few minutes after a person dies, he or she will either be enjoying a personal welcome from Christ, or catching their first glimpse of gloom - the belief in a future irrevocably and eternally fixed by the life a person leads on earth (Lutzer 2000:9; Burger 2003:7). Death is seen as the consequence of Adam and Eve's disobedience in the Garden of Eden, and has three components: spiritual death (separation from God); physical death (their bodies began to decay); and eternal death (if not redeemed by God; Lutzer 2000:28). For these believers hell is founded on the justice of God in punishing sinners, so hell demonstrates the justice of God in a public and unmistakable way and its purpose is understood to be to mete out with exact and final justice what every unrepented of sin deserves (Helm 1989:115-116). The just pain of perdition is seen as having five dimensions: physical discomfort, mental depression, moral depravity, social desolation and spiritual death (Pawson 1992:30). Most have understood this punishment to be endless, as this has been the traditional view of the church for many centuries (Pawson 1992:36). This traditional understanding is sustained by Scripture, first for the fallen angels and then, by association, for sinful humans (Mt 10:32-33, 40-42; 11:20-24; 12:33-37; 13:24-30, 36-43, 49-50; 25; Lk 16:19-31; 18:29-30; Jn 5:24-29; 12:44-48; Rv 7:1-17; 19:19-21; 20:7-15). Though some words and even statements are admittedly ambiguous, others are clear and unequivocal (Pawson 1992:37).

\section{THE TRADITIONAL UNDER FIRE}

The belief mentioned above held its ground right down to the day when the bomb fell on Hiroshima in August 1945 - as since Hiroshima the imagination of modern men and women has been fascinated no longer by burning annihilation (Moltmann 1999:44). The traditional/propositional instruction has been knowingly rejected on grounds that may be grouped into two categories: those which are personal and subjective; and those which are theological and objective (Pawson 1992:15). 


\subsection{Personal aversion}

Many people simply dislike the idea of there being such a thing as hell. They find it uncongenial to the point of becoming intolerable, but their rejection is more intuitive than it is considered (Pawson 1992:16). Sometimes this is due to an imagined or instructed distortion of the Biblical data; however, such exaggeration does not explain all intolerance. Some people have an emotional reaction to hell - those with the greatest ability to empathise have the biggest problem here. Some have an intellectual reaction: the modern mind, considering itself sophisticated and refined, rejects hell as barbaric and primitive (Pawson 1992:16). Such means of dealing with recalcitrant members of the human race are regarded as both crude and cruel, and should therefore not even be discussed in a civilised society. Some have a moral reaction. As psychology and sociology have left their mark we are considered less responsible for our actions, now it is heredity and the environment which determines life for us (Pawson 1992:16). Misfits should be considered as patients or victims, and punishment can only be justified if it is reformatory or deterrent. Retribution is an outdated concept (Pawson 1992:16).

\subsection{Theoretical arguments}

This approach is both theological and logical - usually based on the premise of one of God's attributes the deduction is drawn that hell is simply inconsistent with God's self-revelation (Pawson 1992:19). Three such syllogisms have dominated the field: Firstly, hell is considered incompatible with God's love. Secondly, hell is considered incompatible with God's justice. A sensitivity to injustice is universal to humankind surely God must have the same outlook, only more so. Thirdly, hell is considered incompatible with God's power - if any humans are finally and permanently in hell, then God has failed. Hell would be a monument to God's weakness in that his creatures have been able to resist him, and have therefore proved stronger than their Creator. All these arguments exalt one divine attribute at the expense of others, they emphasise one part to the detriment of the whole (Pawson 1992:21)

\section{HOT CONTENDERS}

\subsection{Universalism}

Universalism is the belief that everyone will finish up in heaven, as salvation is universal and meant for every member of the human race (Pawson 1992:22), since it is said that Christ died for all people without exception. The universality of God's grace is thus grounded on the theology of the cross: 
Judgment is not God's last word, judgment establishes in the world the divine righteousness on which the new creation is to be built (Moltmann 1999:47). God's last word is: "Behold, I make all things new" (Rv 21:5), and from this no one is exempted - making transforming grace God's punishment for sinners (Moltmann 1999:47). Belief in God's perfect goodness prohibits us from affirming that he will punish some people everlastingly for their sins in hell (Van Holten 2003:476). God will not leave us in hell forever. Finally, at the end of all things, God will once again be all in all. Even those who foolishly ran away from God in this life will be reconciled to him in the end (Chinlund 1998:141). God will overcome every remnant of evil and all rational creatures (some would even include Satan) will eventually be redeemed. Universalists like to make use of Paul (Rm 5:18; 1 Cor 15:22) and texts from the Paulinists (Eph 1:10; Col 1:20) to prove their theory (Lutzer 2000:94).

\subsubsection{Variations on the theme}

Two variations of this outlook can be distinguished: The older version was that everybody will be saved sooner or later, implying a second chance after death. If there is any torment it is temporary and hell is only remedial as the doors of hell can be unlocked from the inside - Biblical hints about differing degrees of guilt and variation in punishment are interpreted in terms of assigned periods of time to be served (Pawson 1992:35). The newer version is that everybody has been saved already - Christ has accomplished a cosmic redemption. Atonement has rendered judgment obsolete and the world does not need to be saved, just enlightened. Such thinking is therefore conducive to an emphasis on the universality of God's grace, and the belief in the redemption of all humankind.

\subsection{Annihilationism/Conditional immortality}

\subsubsection{The liberal view}

Annihilationism is the belief that only the saints will survive and live for ever, whereas sinners will be totally eradicated (Pawson 1992:23). So this theory contends that all will not be saved, but neither will any be in conscious torment forever - God resurrects the wicked to judge them, after which they are thrown into the fire and are consumed. Thus hell is annihilation (Lutzer 2000:95).

There are two variations on this theme: Some say extinction occurs at the first death, but more say extinction occurs at the second death. Opinions vary as to how much conscious suffering will be experienced in the time between the first and second death (Pawson 1992:23). Everlasting punishment thus means that God sentences the lost to final and definitive death. 


\subsubsection{The traditional interpretation}

A second theme/interpretation is found among those who accept scriptural authority without demur. They have argued that Scripture does not teach everlasting punishment, but instead the annihilation of the wicked: when the impenitent die they do not go on to await judgement, they literally go out of existence (Helm 1989:117). In this view life after death does not occur in virtue of some original power or endowment of the soul, and death itself is the final punishment (Helm 1989:117). Thus, annihilation is the natural fate of all except for whom the grace of God intervenes to grant eternal life. Hell is simply another name for non-existence and eternal life, then, follows only as a result of the grace of God in Christ. The two main arguments for this view are that Scripture does not teach the immortality of the soul as such, and references in Scripture to those who are outside Christ perishing or being destroyed. In the light of the above arguments hell, considered a place of punishment, cannot exist (Helm 1989:118).

\section{LIFE AFTER DEATH AND THE CONCEPT OF HELL IN THE ANCIENT NEAR EAST}

Neither the gospel writers, nor the later defenders of the Christian faith, lived in a cultural vacuum - they knew the Jewish Scriptures, Greek philosophy and mythology (however indirectly), the practices of the Roman state and the paganism of their neighbours around the Mediterranean (Bernstein 1993:2). No correct understanding of hell is possible, therefore, without taking into account the conceptual background of the ancient world prior to Christianity. Further, because Christianity arose as one religion among many, one cannot reach a full appreciation of the task of forming the Christian concept of hell unless one also considers the competition (Bernstein 1993:2). This study of background is complicated, however, by an important factor - the authors of the sources we perceive as background did not foresee the development of the concept of hell. To say that this background anticipated or prepared the concept of hell would be to attribute to these authors a goal they did not have (Bernstein 1993:2). Despite this methodological difficulty, it is possible to see these prior ideas as contributory to the concept of hell in the sense that they provided options for subsequent authors (Bernstein 1993:2).

\subsection{Broad remarks on the development of hell}

"Hell is a divinely sanctioned place of eternal torment for the wicked" (Bernstein 1993:3): divinely sanctioned because the God/gods who established it could have refrained from creating it and could at any time demolish it; while the word torment stresses suffering and the idea that the resident of hell experiences a fate contrary to what he/she wills. For the 
wicked fulfils the requirement that the damned be justly damned, that they deserve their punishment. This concept of hell arose from an array of approaches to death, the afterlife and justice long present in the Mediterranean world. Though each community added a contribution of its own, we can best understand the process by examining the interplay between the two options that attracted the greatest loyalty and the variations that clustered around them (Bernstein 1993:3).

\subsection{Neutral death and moral death}

Written records expressed the first concept, neutral death, in Mesopotamia in the middle of the third millennium BCE (Bernstein 1993:3; Grey 1969; Spence 1994; Cavendish \& Ling 1980). That view, according to which the dead survive en masse in a pallid half-life without either reward or punishment, later informed classical antiquity through Persia. In the middle of the second millennium the Coffin texts of Egypt's Middle Kingdom articulated the second concept, moral death (Bernstein 1993:3). That view, according to which the dead are judged by the standard of known criteria and then rewarded or punished, later informed ancient Greece through its colonies in Sicily and through the influence attributed to the mathematician and mystic Pythagoras (Bernstein 1993:3). By the end of the fifth century, reflection on these differences intensified: The more important the afterlife became, and the more they were said to result from deeds in this life, the more important it became to know what the consequences of one's actions might be (Bernstein 1993:46). The tendency to regard death as neutral reflected an effort to confine the dead in storehouses or at the limits of the world, where they could not disturb humankind. By contrast, the moral view accentuated the effect that knowledge about the dead were considered to have on the morale and behaviour of the living (Bernstein 1993:107). The range of ideas inspired by the above-mentioned two approaches to death were given an own identity by each of the different societies of the Ancient Near East (ANE), and were available to both Jews and Christians as they were shaping their respective views of the afterlife (Aycock \& Klein 1980; Bernstein 1993:3; Grey 1969).

\section{BABYLONIAN AND EGYPTIAN VIEWS}

The Babylonian underworld is morally neutral. The Babylonians clearly subordinated any moral characterisation of the dead to their definite separation from the living. For the Babylonians, keeping them at a safe distance was crucial. And because so much energy was invested in making the underworld contain all the dead, their moral character faded into insignificance (Bernstein 1993:8; Grey 1969). Moreover, this segregation of 
the dead from the living appears to be productive: it guarantees earthly fertility as it seems to allow the living to proceed with their lives, undisturbed by the dead (Bernstein 1993:9). Life can go on only when the living and the dead respect each others' territory (Bernstein 1993:9). This characteristic segregation of the dead, so fundamental to Babylonian myth, is shared by other cultures too: the Greek Hades and the Hebrew Sheol, in their own ways, reflect similar concerns on the part of their peoples (Bernstein 1993:10). Very different from the tightly sealed Babylonian storehouse of the dead is the distribution of the dead in Egyptian religious texts. In the Greco-Roman world, Egypt was seen as a culture particularly devoted to an elaborate care for the dead (Barret 1991; Budge 1925; Trumbower 2001:13). The archaeology of grave sites confirms that it was still customary in the Hellenistic and Roman periods for the survivors of a wealthy Egyptian to supply the mummified body with food, amulets, images of divinities and figurines representing servants and concubines for the next world (Trumbower 2001:14). The benefit accruing to the dead could be conceived in a physical way, similarly to the Egyptian banquets for the dead (Barret 1991; Budge 1925; Trumbower 2001:14). The dead are believed to be rewarded or punished depending on how well they chose their divine patrons (Bernstein 1993:11). In some texts the Egyptian tradition is explicit about the moral component of its underworld (Bernstein 1993:12; Budge 1925). Here is an underworld divided into zones in which supporters and opponents of the particular gods are segregated according to their devotion to, or neglect of, those gods. Although the punishments are not eternal, polytheism confuses the picture, and spells soften the moral quality of judgment (Barret 1991; Bernstein 1993:18; Budge 1925).

\section{THE GRECO-ROMAN WORLD}

Two interesting phenomena combined to make Greek mythology peculiarly heterogeneous: first, complications arose from the intense localisation of cults, which fragmented the picture from the very beginning; second, it proved impossible to make these localised loyalties mutually consistent (Bernstein 1993:91; Edmonds 2004; Graf 1994; Moncrieff 1994). There was another obstacle to consistency beyond the variety of accounts: no one explanation for death encompassed the whole Greco-Roman cultural audience. Still, in view of the above, the following can be said about death and the concept of hell in the Greco-Roman world (Perowne 1969).

\subsection{Death - no final frontier}

Like their counterparts in the ANE, the ancient Greeks regarded death as neutral, embracing all the dead in nearly the same conditions, chiefly marked 
by strict separation from the living (Bernstein 1993:21; Edmonds 2004; Graf 1994). The dead are sent to the halls of Hades, where they are not grouped by any moral category. The dead do not cease to exist but stay in Hades in the form of a shadow, spirit or apparition (Wright 2003:39-43). Although they suffer from the bleakness of their surroundings, their fate has no punitive quality. They rather suffer from the memory of their life, or the shame they experienced in the manner of their death, but not from the conditions in Hades (Bernstein 1993:26; Homer, Odyssey 10.490-495, 503-540, 11.10-330, 385634, 24.1-204; Ovid, Metamorphoses 10.11-22, 40-55, 61-66; Virgil, Aeneid 6.124-155, 236-326, 384-751, 893-896). So the pain comes from the continuance of their emotion at the time of death, rather than from the nature of the underworld or the fact of death (Bernstein 1993:28; Hillman 1979).

Distinctions of social status brought over from life, memories and aspirations and vicarious pride, or shame at loss of status characterise the dead; but these emotions do not affect their basic condition and, as compared to the fact of death, the place itself adds nothing (Bernstein 1993:33; Homer, Odyssey 10.490-495, 503-540, 11.10-330, 385-634, 24.1-204; Ovid, Metamorphoses 10.11-22, 40-55, 61-66; Virgil, Aeneid 6.124-155, 236-326, 384-751, 893896). The one consolation seems to be knowledge of compensatory glory acquired by one's descendants, particularly sons (Bernstein 1993:30). There is no cure for death and no resurrection is possible (Richardson 1985:50-66; Riley 1995:23-24; Porter 1999:68-70). Immortality, as was the case in ancient Judaism, could be found in the leaving behind of a honourable name which would always be remembered. But the underworld was no sealed vessel - on the contrary, both Greece and Rome devised escapes from death and exceptions for their heroes. This porosity of death forms the penumbra of hell, a background without which its own contours cannot be discerned (Bernstein 1993:106; Burkert 1979). A new conception pulled the dead in closer to the communities of the living, and the passages which lead down to the underworld and through which the dead could come out proliferated (Bernstein 1993:90; Homer, Odyssey 10.490-495, 503-540, 11.10-330, 385634, 24.1-204; Ovid, Metamorphoses 10.11-22, 40-55, 61-66; Virgil, Aeneid 6.124-155, 236-326, 384-751, 893-896). The multiplicity of places associated with departure and return from the underworld shows two aspects: first, that many towns desired their own special access; and second, that such points lost their mythic power as they proliferated (Bernstein 1993:89). The decentralised pattern of Greek religion may help account for the many successful raids on the netherworld. Indeed, living heroes invaded the land of the dead so often that they nearly lost their mythic overtones (Bernstein 1993:88). 


\subsection{Hades and Tartarus}

It appears that the notion of a distinction of fates in the Greek afterlife arose later than the concept of neutral death, or visits to the dead with their roots in the older Mesopotamian ideas (Bernstein 1993:50; Edmonds 2004; Morford 1985). This chronological sequence is significant because it suggests that the division of the dead occurs in part as an objection to the older view (Bernstein 1993:50; Burkert 1979; Edmonds 2004). Now two different traditions concerning life after death began to exist, and two kinds of dead are identified: first, the human souls of all ranks who wander without punishment but wearied by their memories of life; second, a group of superhuman rebels sentenced to undying exertions for unspecified insubordination against the divine order (Bernstein 1993:22; Burkert 1979; Edmonds 2004). The souls of the common dead are characterised in a negative way - on the whole they are witless shades who lack precisely those qualities that make up an individual (Van Eck 2004:562). These two different aspects of the otherworld are: the one a land called Hades for the human dead of all sorts; the other a prison for superhuman rebels (titans and monsters) - Tartarus. This distinction between Tartarus and Hades became a crucial aspect of the cultural environment from which the concept of hell emerged (Bernstein 1993:38; Homer, Odyssey 10.490-495, 503-540, 11.10-330, 385-634, 24.1-204; Ovid, Metamorphoses 10.11-22, 40-55, 61-66; Virgil, Aeneid 6.124-155, 236-326, 384-751, 893-896) as the distinction between punishment and mere existence in death comes, in some sources, to affect the view of death itself (Bernstein 1993:33; Stewart 1966). Now it is believed that the soul goes to Hades to be judged, after which the righteous go to the Fields of Elysium and the bad souls go to Tartarus (Van Eck 2004:563).

\subsection{Plato on death and punishment}

A further development in the Greek understanding of life after death is found in Plato. He was fascinated with the notion of post-mortem retribution, and encouraged acceptance of post-mortem punishment (Bernstein 1993:52). Plato argues that, when a person dies, the mortal and immortal parts are separated; the soul survives death, and its fate in the next world depends on how well one has prepared it in this world, as the soul is believed to have its own individuality and identity and continues to bear the signs of its life (Bernstein 1993:54, 56). After death the soul moves through an interim period of reward or punishment. The dead are assigned to different regions in Hades at the judgment after their deaths, and four fates are possible: that of the holy, that of those who have lived lives of indeterminate character, that of those guilty of sins that can be expiated and that of the incurably wicked (Bernstein 1993:55). The morally pure are sent to Acheron where they dwell at the lake until they are purified, paying penalties for misdeeds and receiving rewards for 
any good deeds. The incurable are cast into Tartarus for eternal punishment, as they committed actual misdeeds that produce active punishment (Bernstein 1993:68). Others are judged curable - though these too are sent to Tartarus, the oscillations of the earth wash them out annually. Finally, those who are judged to have led holy lives are freed entirely from these cycles within the earth - they move without bodies to the pure regions, Elysium, where they share the ether with the gods and are granted their freedom and experience positive joy (Bernstein 1993:55, 68; Stewart 1966). Plato's distinction between the curable and the incurable directly confronts the issue of eternal punishment. After being purified by their punishment in Tartarus, the curable return to a new life. The incurable never do: they suffer throughout eternity, and these punishments are of no benefit to them. They serve as examples, a horror and a warning for other evildoers so that they may take fright and amend their lives accordingly. The eternal punishment of the incurable thus deters the curable as they serve their time in Tartarus in the process of renewal (Bernstein 1993:57; Stewart 1966).

\section{THE AFTERLIFE IN ANCIENT JUDAISM AND EARLY CHRISTENDOM}

It is important to remember that the different approaches to death and punishment after death which occur in the Hebrew Bible do not develop toward some perfect or more sophisticated position. Rather, the different positions expressed simultaneously reflect various sensibilities within the religious community (Bernstein 1993:167). The Jewish community was too diverse, the concerns of the writers too varied and the circumstances that provoked reflection too changeable to propose a single straight line (Bernstein 1993:134). These different traditions are combined in various, often inconsistent-looking ways (Räisänen 2007:2), which oftentimes makes it impossible to decide which conception is present in a text as the two views are found side by side, there is no clear cut boundary.

\subsection{Death: A shady existence in Sheol}

Few Israelites ever thought that death would be the end of everything - a distinction between the body and something that might be called the soul or spirit was current in Israel and elsewhere in the ancient world (Räisänen 2006:4). The existence of the dead in Sheol came to be conceived of as an existence of shades void of vitality and joy, and an equal state of misery awaited all who died (Räisänen 2006:4). Life after death was nothing more than a sort of shadowy existence in Hades/Sheol underneath the earth. It was a life of silence in which there was no possibility of contact with Yahweh or 
with the cult (Van Eck 2004:556) - according to Genesis 3:9; Job 3:13-19; 7:9-10; 14:10-15, 21; 19:25-27; Psalm 6:5; 16:10; 30:9; 39:13; 49:15; 88:3-10; 115:17; 146:4; Ecclesiastes 2:14-16; 3:20; 9:4-5; Isaiah 38:10-18. Sheol was seen as a wilderness: a place of dust to which creatures made of dust have returned. Several apocryphal texts paint the same picture that there is no life after death - Tobit 1:17-18; 3:6; Sirach 14:17-18; 17:28; 38:20-23; 41:1-4 and The Wisdom of Solomon 6:17-20 (Van Eck 2004: 556). The only life after death, according to Sirach (30:4-6; 44:13-14), was the leaving behind of an honourable name which will never be forgotten (Van Eck 2004:556) and having children (especially boys; see Riley 1995:10-13; Segal 1997:96; Craffert 1999:46; Wright 2003:99-100). This view of life after death was connected to the pre-exilic understanding of God as a God of the living, not the dead (Kaplan 1988:8). Such ideas of Sheo/ were close to the Greek conception of a common destiny awaiting all.

\subsubsection{Justice under review}

The notion that God rules the universe from its farthest limits to its innermost recesses and the suggestion that, with God's help, one can avoid death or Sheol also carry the implication that God's anger can send one there directly (Bernstein 1993:145). So God can send people down to the depths suddenly or, favouring them, recall them from the brink (Bernstein 1993:146). This explicitly makes divine punishment a sanction enforcing adherence to religious authority (Bernstein 1993:145). However harsh the penalties, they are due for breach of contract (Bernstein 1993:148). This then is the Deuteronomic outlook: obey and prosper; turn away and perish, and it applies whether the evildoers are one or many (Bernstein 1993:148). There are sayings that describe the punishment of wickedness by the wicked deed itself - by this mechanism one punishes oneself by one's own wicked actions, and the harm one does is harm to oneself. In this view the world is so composed that the perpetrator of evil becomes his or her own victim. This is called reflexive justice, and it also works for whole peoples (Bernstein 1993:151). But the armies of Judah and the administrators of its cities could not cleanse the world of evil on their own - which led to a mounting perception of worldly injustice and the proliferation of questions regarding the fate of the wicked (Bernstein 1993:152). What happens to the wicked that die at the height of their wealth and power? Do they ever receive their just deserts? The seekers of an alternative solution saw too many evildoers who were not cut off from life. Within the Jewish community itself the greedy and ambitious suffered no horrible end (Bernstein 1993:154). Thus the Bible records doubts about the Deuteronomic system - to many people it seemed that God waited too long to 
visit ruin on the wicked. Since there seemed to be no difference between the good and the evil in life, perhaps they might know some difference in death a call for moral death begins (Bernstein 1993:156).

\subsubsection{Gehenna: A concept is born}

The separation of good and evil in the afterlife did not grow exclusively from the deepening of Sheol or the naming of areas within it; another place came to exercise many of the same functions simultaneously. That place was a ravine called the valley of the sons of Hinnom (Bernstein 1993:167). The translators of the Hebrew Bible into the Greek Septuagint transliterated this name as Gehenna, and early Greek-speaking Christians preserved this term. As they wrote the New Testament they distinguished Hades from Gehenna (Bernstein 1993:167). The word Gehenna is used in the Bible in four different senses:

The first sense is merely a reference to a piece of land. The valley of Hinnom is known as the boundary between the inheritance of Judah and Benjamin, and later as the northern border of Judah. However, the valley is mostly renowned for the worship of the gods Molech and Baal. Partly for this reason, and partly because of its convenient location and depth (steep cliffs confined the heat and the smell) Gehenna was forever tainted, and the valley became the city's garbage dump. The waste was kept down in two ways: incineration by fire of what was combustible, and ingestion by worms of what was digestible. In Jesus' day it also had criminal associations - the corpses of crucified felons were thrown into Gehenna (Pawson 1992:29). Thus, death would always be associated with the spot, and this made the valley ripe for metaphorical extension into a place of torment (Bernstein 1993:169).

A second meaning for the word is found in the prophecy of Jeremiah here it refers to an extraordinary place of punishment for the wicked in the environment of Jerusalem. In condemning the valley as a place of idol worship, Jeremiah anticipated that it would become a valley of slaughter for those who worship there.

The third meaning follows from this, as from this point on it was a small step for Jewish apocalyptic thought around the first century BCE to see the valley of Hinnom as the place where all the enemies of God would be destroyed in the final day of judgment. This shift from a place of judgment to a place of punishment was a logical development; from a valley geographically associated with Jerusalem, Gehenna acquired the metaphorical meaning of a place of judgment and fiery punishment at the end of times (Craffert 1999:79).

The final step in the development of this concept is to see Gehenna as an other-worldly place of punishment for the wicked after death (Bernstein 1993:170). The social and political situation of persecution and oppression triggered a reconsideration of the traditional views about the afterlife and postmortem rewards. The Book of Watchers in I Enoch is probably the first text in 
the Jewish tradition to juxtapose and yet distinguish Sheol and Gehenna - the first is a holding place for all dead until the judgment; the second is a place of eternal punishment for the wicked (Bernstein 1993:187). So for the first time in Judean literature one finds an alteration in how the realm of the dead is seen

- instead of Sheol as the everlasting residence of the dead, it becomes the pathway to something else (Craffert 1999:50).

\subsubsection{Textual evidence}

The fire and the worms that consume the damned first appear in Isaiah 66:24 in the context of historical eschatology as the burning corpses of apostates are on display near Jerusalem; yet this very passage seems to have suggested the idea of a fiery hell when the fire and the worms of Isaiah 66 later repeatedly appear as epithets of a place of torment (Räisänen 2007:2). Some texts strongly suggest annihilation or extinction of the impious - 1 Enoch 1:9; 1 QpHab 13; CD 2:5-7 and 2 Maccabees 7:14 (Räisänen 2007:2). In other texts it remains unclear whether the destruction of the sinners means a once-and-for-all extinction or else a lasting state - the Psalms of Solomon 3:11; 15:10-13 and 1 Enoch 98:10-13; 100:9; 102:1; 103:7; 108:3 (Räisänen 2007:2).

In still other texts the idea of a prolonged torment before annihilation can be found - 1 QS 4:12-14; 4 Ezra 7:36, 61, 75; 8:59; Pseudo-Philo 18:12; 23:6 and 1 Enoch 48:8-10; 54:6; 63:10 (Räisänen 2007:3). Yet other texts leave no doubt that eternal torment awaits the sinners - 1 Enoch 22:10; 27:2; the Book of Judith 16:17; 4 Maccabees 9:9; 13:14; 2 Baruch 44:12; 59:2; 85:12-13; the Apocalypse of Zephaniah 4:7; 6:2; 2 Enoch 10; 40:12 and the Sibylline Oracles 2:283-312 (Räisänen 2007:3). In most of the texts presented so far the sinners (they) are collectively contrasted to the righteous (us) and the visions of punishment are actually meant as encouragement to the ingroup: their afflictions will come to an end, while their oppressors perish one way or another (Räisänen 2007:4). Many of the texts which most clearly presuppose eternal torment are roughly contemporary with the gospels, and most probably not part of the earliest Jesus tradition (Räisänen 2007:4).

\subsection{Hell in the New Testament}

Behind the New Testament lies some background knowledge in the form of a time line or narrative upon which its writers drew freely, but usually silently. Distinct from the actual Biblical text, yet underlying and in a certain way explaining it, the antecedent background story must be called the myth (Bernstein 1993:248) as it functions like a myth - a powerful narrative that guides and even scripts the imagination and thinking of a people as they work out their place in the world. It conveys the driving force exercised by the 
constellation of images, precepts and behavioural models conveyed by the New Testament (Bernstein 1993:249). The New Testament authors strove to set the historical moments within a single time frame, a history of the world moving from creation to a never-ending eternity after the end of time. Drawing significantly upon key elements of Jewish belief, it runs from the mythic past in creation, the expulsion from Eden, the fall of the angels; through the virgin birth, the temptation, the crucifixion, the descent into Hades, the resurrection and into the mythical future (the parousia, the general resurrection and the last judgment); to name only the most salient points (Bernstein 1993:248). Statements that can be explained in terms of prior events, a mythic past, show that some story about a prior relationship between God and Adam, Adam and Christ, Satan and Adam, Jesus and Satan, lies in the background - that background is the myth (Bernstein 1993:249).

The clarity of that negative vision would increase with a more careful balancing of the mythic material (Bernstein 1993:251). The symmetry used to shape and interpret the mythical past could also be used to extrapolate a mythical future and to forecast human destiny: judgment followed by eternal life or eternal damnation (Bernstein 1993:252).

\subsubsection{Hell in context}

The focus of Christianity is on eternal life, not punishment after death. Christians hold that by the divine sacrifice of Christ it becomes possible for humanity to imitate Jesus' resurrection through the reunion of the soul with a body made spiritual, forming a renewed person who will enjoy eternal bliss in the kingdom of God. For the Christian, death - the last enemy - is conquered and Hades is overthrown (Bernstein 1993:205). Developing the implications of the apocalyptic strand of late ancient Judaism, Christianity broke definitively with the Greek notion of cycles and proclaimed linear, teleological time - the Christian view of history develops along a line from creation to redemption and resurrection. For the individual there is only one life, thus death becomes the deadline for conversion and right action (Bernstein 1993:205). But what does the New Testament teach concerning those that are not saved?

The first possibility is mere death: those who fall short simply remain in their graves, decompose and pass into nothingness. That would be natural/simple death, or what the New Testament calls destruction (Bernstein 1993:206). A second view holds that simple death does not suffice: justice demands retribution. Those that reject the Christian message will also be resurrected, but then they will be sent to a fate separate from and worse than that of the blessed (Bernstein 1993:206). Other Christians proposed a third 
possibility: universal salvation, as surely God would eventually draw all to Himself, even if after punishment (Bernstein 1993:207)?

\subsubsection{The Synoptic gospels: Placing the Jesus tradition on the continuum}

One can trace several different trajectories from Jewish to early Christian tradition (Räisänen 2007:8), in which common imagery is used: fire, worms, darkness, wailing, weeping and gnashing of teeth, a lake of fire. Clearly a Jesus who speaks of lasting torments would be a plausible figure both in the Jewish and the early Christian context, but a Jesus who speaks of annihilation would also fit (Räisänen 2007:8). As the most likely cases in early Christian sources are found in the Synoptic gospels, it is more natural to place the Jesus tradition on the lasting torment trajectory than on the annihilation line (Räisänen 2007:8). Theissen and Winter (in Räisänen 2007:8) work out two criteria for plausibility for the Jesus quest: the criterion of contextual plausibility (which states that, while Jesus should fit into the Judaism(s) of first-century Palestine, while some individual traits should also be visible) and the plausibility of influence criterion (indications of authenticity may be seen in multiply attested features and in features that go against the tendencies of the source).

References to a place of punishment are multiply attested in Q, Mark and the materials peculiar to Matthew and Luke (Räisänen 2007:9). Several of the hell sayings breathe an embarrassing harshness, towards members of the in-group (Mk 9:42-48; 10:29-31; Mt 5:27-29; 7:13-14, 19, 21-23; 8:10-12; 10:26-28; 18:6-9; 19:28-30; 20:16; 21:31-32, 43; 22:1-14; 24:31, 45-51; 25; Lk $8: 16-18 ; 10: 13-15 ; 12: 4-5,35-48 ; 13: 22-30)$ ! When reading the Synoptic gospels it seems that Jesus spoke of final condemnation, a natural thing to do for a Jewish preacher, which explains the central role that hell came to have in early Christian discourse - here the continuum is clear (Räisänen 2007:9). But the fact that severe threats of hell are, time and again, addressed as warning exhortations to the in-group is a feature which cannot easily be traced back to Jewish tradition - a point where the Synoptic Jesus shows individuality within the first-century Palestine Jewish context (Räisänen 2007:9). This harshness of Jesus' message was taken up and intensified by many in the Jesus movement (e. g. the gospel writers), analogous to contemporary developments in a harsh direction on Jewish soil (Räisänen 2007:9).

The Synoptic gospels explicitly evoke eternal punishment as the fate of those who persecute the church, behave immorally or fail to accept the faith (Bernstein 1993:228). Some passages explicitly refer to Gehenna: they describe it as a fire, call it eternal and declare it to be the fate of those found 
wanting at the last judgment. Three crucial passages in the Synoptic gospels helped form the concept of hell - Mark 9:42-48 and Matthew 25:30, 31-46 call the place of punishment Gehenna; Luke 16:19-31 refers to Hades, but the suffering of the sinner described there puts this passage at the punitive extreme of the classical Hades or the Hebrew Sheol (Bernstein 1993:228). What emerges is reflexive punishment similar to the pattern in the Hebrew Scriptures.

\subsubsection{Developed traditions}

Paul and the Paulinists did not have a clear idea about hell, as their concern was more intently focused on the positive side of the Christian message (Bernstein 1993:207). Paul never used the word Gehenna, and in the one place he refers to Hades it is in the context of celebrating the resurrection of the flesh and the defeat of death (1 Cor 15:54-55). According to 2 Corinthians $5: 10$, for Paul judgment was a reality, but the netherworld was no prison. As the kingdom beckoned, Hades faded and it remained at most a memory (Bernstein 1993:208). Paul's letters reveal that, although he was extremely attracted to the third option, he actually adopted the first - annihilation. His consciousness of the need for a human response to the opportunity offered by redemptive action convinced him that those without faith, or guilty of evil action, are excluded from eternal life (Bernstein 1993:208). This provision is vitally important as it provides the rationale for excluding those who did not make the request, give the indication and did not show receptivity to grace (Bernstein 1993:216).

John's gospel is the closest to Paul in spirit as, like Paul, the school of thought of the Johannine tradition holds that judgment probes for faith and that those lacking faith will suffer exclusion, wrath and destruction (Bernstein 1993:225). Thus belief is the key to eternal life, and judgment will test for that faith. The biggest contrast is that the Johannine tradition is free of Paul's hesitation about any mention of those who fail in the divine scrutiny - his position is the solution that the Paulinists arrived at only gradually: the judgment by the Son on the authority of the Father will yield eternal life for those who believed, but judgment, wrath and death for those who did not (Bernstein 1993:225). Revelation links death and Hades and distinguishes them from the Lake of fire, a subsequent receptacle for the wicked dead equivalent to Gehenna (Bernstein 1993:254) The devil joins the beast and the false prophet; death and Hades, now deprived of all their prey, are consigned there; and everyone whose name was not found written in the book of life is thrown into the lake. The torments of the lake of fire will last as long as the second death that follows the last judgment (Bernstein 1993:259). 


\subsection{Post-New Testament views}

Some early Christians continued the tradition in which annihilation or extinction of the condemned was envisaged - the terms apollysthai and apoleia in Paul (1 Th 4:16; 1 Cor 15:23) probably refer to annihilation as the final goal that God is all in all (apokatastasis: Rm 5, 11; 1 Cor 15) and hardly leaves room for the continued existence of evil (Räisänen 2007:5). The notion of a temporary torment in hell also had its representatives among early Christians - the Ascension of Isaiah 4:14-18 and the Apocryphon of John 26:33-27:11 (Räisänen 2007:5). The Dialogue of the Saviour 127:16-17 later also uses this formula. The other, better-known Apocalypse of Peter later gives a full description of hell. Featuring darkness, fire, worms and venomous beasts; this text revels in the horrendous punishments which correspond to the transgressions. Less visual, but hardly less serious, many other authors confront their readers with the terror of the unquenchable fire -2 Clement 17:5-7; the gospel of Phillip 66:27-67:1; Polycarp's Mart Pol 11:2 and 1 Apol 12:1-2, 45:5 (Räisänen 2007:8).

\section{HELL: SOMETHING OLD AND SOMETHING NEW}

\subsection{Resultant remarks}

Theologians should naturally be wary of conforming too readily to contemporary culture in their exposition of the Christian faith. Coherence with tradition is a virtue in theology, and rejection of traditional sources of authority threatens to reduce theology to subjective speculation and leave Christianity with no clear identity and content (Van Holten 2003:458). But this does not mean that an appeal to Biblical and ecclesiastical tradition is always decisive, nor does it mean that revision is never appropriate. It does entail that doctrinal deviation from tradition should not originate from some unanalysed conviction about what modern people can/can no longer believe in - it should be preceded by an exposition of the untenability of traditional claims and be based on rational arguments.

For this reason attention has been given to the origin and development of the ideas and concepts that served as source for modern ideas. It has been shown that, originally, the concepts of hell and punishment arose to deal with issues of justice and redemption. Circumstances developed in which there was no experience of justice and no hope for redemption, as all efforts at both were thwarted time and again. A feeling of powerlessness and helplessness arose, which was countered by the belief in ultimate and final redemption and punishment - though maybe not in this life, surely in the next the righteous 
would be vindicated. A shift in the expectation for justice - redemption for the righteous and punishment of the wicked - thus occurred to a life after death.

\subsection{The scholarly approach versus the popular notion}

It has been shown that the perception exists among scholars and leaders today that humankind lives as if they will be on earth forever; and death, when it is faced, is sentimentalised (Helm 1989:12). For them, the idea of judgement and division runs counter to the spirit of the age (Helm 1989:12). But a deeper reason for the rejection of the idea of hell has to do with the justice of God: they assume it to be impossible for a just and loving God to send anyone to hell. There are many signs of this: One sign is the shift away from an emphasis upon personal sin to what is called structural sin. Another is the increasing emphasis being placed upon the pleasure principle outside and inside the church. And yet we have seen that popular culture is following a different road - whereas hell has disappeared from most modern scholarship and Christian leadership, it has become one of the hottest topics in popular culture and literature. In this context, the concept of hell is seen as one of the most central parts of Christian doctrine, and the loss of hell as a tragedy to be mourned because then all possibility of final justice is lost. It is interesting to note that, as was the case in the first few centuries, a socio-cultural situation of the experience of oppression and injustice has led to the renewed rise in the popularity of hell.

Though humankind is not oppressed by great kingdoms and people are not forced to surrender their free will, a vague sense of threat is experienced everywhere - the earth and our environment is becoming a danger to us, we experience the vague and faceless threat of terrorism and in our idealist approach to human freedom and punishment is almost impossible to mete out. The general feeling is one of being under attack, with no possibility of real justice and retribution in the here and now. Thus the modernist shift of judgement and punishment into the here and now of the human field has been shown to have been ineffective. And, just as in the first centuries, this has led to an ever greater emphasis being placed on justice - redemption/reward and punishment - in the life to come. People demand a moral universe - because it is perceived that, if this life is all there is, then injustice reigns. But if there is a life beyond, and it includes retribution for the evildoer, then it becomes possible to believe again that righteousness rules and that God is good. To that extent, the idea of hell is good news (Pawson 1992:5); as even if the wicked escape the penalties and consequences of their crimes in this world, they haven't got away with it. 


\section{CONCLUSIONS}

It has become clear that there is a connection to be made between the ancient origins and the modern interpretations of hell. Not only have the same different concepts of hell that were popular in ancient times become popular once again today; it has also been shown that there are major correlations between the reasons for their rise in popularity then and now. In these different times the same socio-cultural feelings of oppression, threat and injustice have lead to the rise of similar ideas about the afterlife and hell. Though modern science is in the business of the invention of new concepts, it has been shown that all the new concepts of hell can be traced back to ancient origins. This said, it is clear that the formation and development of concepts and systems of belief cannot be separated from the socio-cultural environment in which they are born - illustrated by the seemingly unconnected ancient and modern concepts of hell, proven with this study to be connected both in the socio-cultural circumstances of their origin and the content of their concepts. This insight into the development of the different ideas about the afterlife and its conditions, coupled with an awareness that these ideas were and still are connected to social and political circumstances, makes it easier to accept that modern people need not necessarily accept the exact content of the New Testament in order to be faithful to that tradition (Craffert 1999:82).

Doing away with everlasting punishment in a fiery hell need not entail a denial of the idea of retribution in itself. There is nothing unethical in the notion of a post-mortem judgement; on the contrary, such a judgement may well seem desirable from an ethical point of view - if it does not take place on an "absolute right-wrong" basis and if the punishments are not extravagant or eternal. Whether one can still believe in such a judgement in the framework of a modern world-view is another question, and so is the question whether one can get rid of hell without simultaneously losing heaven.

\section{Works consulted}

Alighieri, D 1971. The divine comedy, Vol 1: Inferno. New York: Penguin Books.

Aycock, W M \& Klein, T M 1980. Classical mythology in $20^{\text {th }}$ century thought and literature. Lubbock, TX: Texas Tech.

Bauckham, R (ed) 1999. God will be all in all: The eschatology of Jürgen Moltmann. Edinburgh: T\&T Clark.

Barret, C 1991. The Egyptian gods and goddesses: The mythology and beliefs of Ancient Egypt. London: Aquarian Press.

Baxter, M K 1993. A divine revelation of hell. New Kensington, PA: Whitaker House.

Bernstein, A E 1993. The formation of hell: Death and retribution in the ancient and early Christian worlds. Ithaca, NY: Cornell University Press. 
Bloch-Smith, E M 1992. Judahite burial practices and beliefs about the dead. Sheffield: JSOT.

Budge, E A W 1925. The Egyptian heaven \& hell: Being the book of Am-Tuat, the shorter form of the book of Am-Tuat, the book of the gates and the contents of the books of the other world, described and compared by Ernest $A$ Wallis Budge. London: Martin Hopkinson.

Burger, I 2003. Die eerste 5 minute na die dood: Wat gebeur as 'n mens sterf? Vanderbijlpark: Carpe Diem Media.

Burkert, W 1979. Structure and history in Greek mythology and ritual. Berkeley, CA: University of California Press.

Butcher, S H \& Lang, A (eds) 1909. The Odyssey of Homer. New York: Collier. (Harvard Classics.)

Cavendish, R \& Ling, T O 1980. Mythology. London: Black Cat.

Chinlund S J 1998. Healing and hell: The contradiction. Journal of Religion and Health 37(2), 137-142.

Clayton, P 1990. A-Z of mythology. London: Bison Books.

Cooper, J S 1992. The fate of mankind: Death and the afterlife in ancient Mesopotamia, in Obayashi, $\mathrm{H}$ (ed), Death and afterlife. New York: Praeger.

Cotterell, A 1991. A dictionary of mythology. Oxford: Oxford University Press.

Craffert, P F 1999. Meeting the living among the dead: Perspectives on burials, tombs and the afterlife. Pretoria: Biblia.

Die Afrikaner 25 Januarie 1996. Die hel se probleem, bl 6.

Die Beeld 24 Mei 2004. "Skok wag op Nuwe Hervormers ná dood", bl 3.

Die Beeld 16 Januarie 1996. Verslag oor die hel lok wye reaksie uit, bl 5.

Die Beeld By 2 Junie 2007. Makliker gesê as gedaan ..., bl. 7.

Dulles, A 2003. The population of hell. First Things 133, 36-41.

Edmonds, R G 2004. Myths of the underworld journey: Plato, Aristophanes, and the "Orphic" gold tablets. Cambridge: Cambridge University Press.

Fairclough, H R (ed) 1916. Virgil I. Cambridge: Harvard University Press. (Loeb Classical Library.)

Goold, G P (ed) 1979. Ovid in six volumes, translated by J H Mozley et al. Cambridge: Harvard University Press. (Loeb Classical Library.)

Graf, F 1994. Greek mythology: An introduction. Northampton: Johns Hopkins University Press.

Grey, J 1969. Near Eastern mythology. London: Hamlyn.

Helm, P 1989. The last things: Death, judgement, heaven and hell. Edinburgh: The Banner of Truth Trust.

Hillman, J 1979. The dream and the underworld. New York: Harper \& Row.

Insig Junie 1991. Ja, daar is 'n hel, bl 20.

Insig Junie 1991. Die hel is 'n ou, ou storie ..., bl 22.

Isbell, H (ed) 1990. Ovid Heroides. London: Penguin. (Penguin Classics.)

Lewis C S 1980. The weight of glory and other addresses. New York: Macmillan.

Lutzer, E W 2000. One minute after you die: A preview of your final destination. Vereeniging: Christian Art Publishers.

Martindale, W \& Root, J 1989. The quotable Lewis: An encyclopaedic selection of quotes from the complete published works of C S Lewis. Illinois, IL: The Marion E Wade Centre. 
Miller, F J (ed) 1916. Ovid metamorphoses. Cambridge: Harvard University Press. (Loeb Classical Library.)

Moltmann, J 1999. The logic of hell, in Bauckham, R (ed), God will be all in all: The eschatology of Jürgen Moltmann, 43-47. Edinburgh: T\&T Clark.

Moncrieff, A R H 1994. Classical mythology. London: Senate.

Morford, M P O 1985. Classical mythology. London: Longman.

Morris, L 1991. Hell: The dreadful harvest. Christianity Today 35(6), 34-38.

Obayashi, H (ed) 1992. Death and afterlife. New York: Praeger.

Pawson, J D 1992. The road to hell. London: Hodder \& Stoughton.

Perowne, S 1969. Roman mythology. London: Hamlyn.

Räisänen, H 2007. Jesus and hell. Unpublished paper delivered at SBL Conference, Vienna.

Räisänen, H 2006. Towards an alternative to New Testament theology: "Individual eschatology" as an example, in Rowland, C \& Tuckett, C (eds), The nature of New Testament theology, 167-185. Oxford: Blackwell.

Räisänen, $\mathrm{H}$ 2005. Hell in the Bible and in Christian history: Towards a moral criticism. Unpublished paper delivered at a Seminar on reception history, Oxford.

Rapport 1 Augustus 1991. Hemel, hel is g'n "plekke", sê pous, bl 13.

Rapport 9 Februarie 1997. Satanisme se houvas 'n voorsmaak van hel, vertel seun, bl 16.

Rapport 18 Februarie 1996. Só is die hel, sê Anglikane nou - maar Jode verskil, bl 18.

Rhoades, J (ed) 1952. The Poems of Virgil, tr into English verse by J Rhoades. Chicago, IL: Encyclopaedia Britannica. (Great Books of the Western world.)

Rhoades, J (ed) 1921. The Poems of Virgil. London: Oxford University Press. (World's Classics.)

Rowland, C \& Tuckett, C (eds) 2006. The nature of New Testament theology. Oxford: Blackwell.

Rutherford, R B (ed) 1996. Homer. Oxford: Oxford University Press. (New surveys in the classics 26.)

Segal, A F 1996. Some observations about mysticism and the spread of notions of life after death in Hebrew thought. SBL 1996 Seminar Papers, 385-399.

Atlanta, GA: Scholars Press.

Seymour, C 1997. On choosing hell. Religious Studies 33, 249-266.

Slavitt, D R (ed) 1992. Virgil. New Haven, CT: Yale University Press. (Hermes Books.)

Spence, L 1994. Introduction to mythology. London: Senate.

Stewart, Z 1966. The Ancient world: Justice, heroism, and responsibility. Englewood Cliffs, NJ: Prentice Hall.

Stone, M E 1990. Fourth Ezra. Minneapolis, MN: Augsburg Fortress.

Stoddard, E \& Pryce, G 2005. Observed aversion to raising hell in pastoral care: The conflict between doctrine and practice. JET 18(2), 129-153.

Sunday Times, 8 October 2006. Pope ends limbo dance, $\mathrm{p} 7$.

The Citizen 17 July 1999. Hell - putting it in a "modern perspective", p 7.

The Citizen 17 July 1999. No hell below, p 12.

The Doctrine Commission of the Church of England 1995. The mystery of salvation:

The story of God's gift. London: Church House Publishing. 
The Star 15 January 1996. Prepare for a new kind of hell, $\mathrm{p} 6$.

Thomas, C 2003. Heaven is so real! Lake Mary, FL: Creation House Press.

Toynbee, J C M 1971. Death and burial in the Roman world. Baltimore, MD: Johns Hopkins University Press.

Trumbower, J A 2001. Rescue for the dead: The posthumous salvation of nonChristians in early Christianity. Oxford: Oxford University Press. (Oxford Studies in Historical Theology.)

Twain, M 1962. Letters from the earth: Uncensored writings. New York: Harper \& Row.

Van Eck, E 2004. Die opstanding in die Jodedom, die Grieks-Romeinse wêreld en die Nuwe Testament. HTS 60(1\&2), 555-574.

Van Holten, W 2003. Can the traditional view of hell be defended?: An evaluation of some arguments for eternal punishment. AThR 85(3), 457-476.

Von Balthasar, H U 1988. Dare we hope: "That all men be saved"?: With a short discourse on hell. San Francisco, CA: Ignatius Press.

Vorster, W S 1991. Jesus the Galilean. HTS 47(1), 121-135.

Weekend Post 27 November 2004. Heaven's to die for, says pastor, after decidedly hellish journey, $\mathrm{p} 3$.

West, M L (ed) 2003. Homeric hymns, Homeric apocrypha, lives of Homer.

Cambridge: Harvard University Press. (Loeb Classical Library.)

Wetzel, J 2002. A meditation on hell: Lessons from Dante. MoTh 18(3), 375-394.

Williams, R D (ed) 1967. Virgil. Oxford: Clarendon. (New surveys in the classics 1.) 